\title{
THE IMMEDIATE EFFECTS OF RESPIRATORY DEPRESSION ON ACID-BASE BALANCE IN ANESTHETIZED MAN 1
}

\author{
By DUNCAN A. HOLADAY, DOROTHY MA, AND E. M. PAPPER \\ (From the Department of Anesthesiology, Columbia University College of Physicians and \\ Surgeons, and The Presbyterian Hospital, New York, N. Y.)
}

(Submitted for publication September 6, 1956; accepted March 21, 1957)

The earliest report of the immediate effects of elevated carbon dioxide tension on acid-base balance during anesthesia was published by Henderson and Haggard in 1918 (1). They observed that an increase in $\mathrm{CO}_{2}$ tension of the pulmonary air resulted in an increase in the $\mathrm{CO}_{2}$ capacity of the blood of narcotized dogs. They postulated that this change was due to the passage of alkali from tissues into blood and resulted in the maintenance of the hydrogen ion concentration of the blood at a normal or nearly normal level. In 1932, Shaw and Messer (2) reported similar experiments with contrary results. They observed that dogs breathing high concentrations of carbon dioxide invariably developed a significant reduction of $\mathrm{CO}_{2}$ capacity of the blood. When these experiments were repeated in cats, the alteration was even more striking. They suggested that the elevated blood bicarbonate, resulting from $\mathrm{CO}_{2}$ retention, migrated into tissues as a result of physical forces which were regulated by the ionic concentration gradient.

Recently, Giebisch, Berger, and Pitts (3) and Elkinton, Singer, Barker, and Clark (4) have observed responses to $\mathrm{CO}_{2}$ breathing in anesthetized dogs and unanesthetized man, respectively, which confirm the observations of Henderson and Haggard. On the other hand, Himwich, Gildea, Rakieten, and DuBois (5) consistently observed a reduction of $\mathrm{CO}_{2}$ capacity in unanesthetized humans breathing 5 per cent $\mathrm{CO}_{2}$ for 30 minutes. The same authors obtained this response in four of six experiments on dogs during $\mathrm{CO}_{2}$ inhalation of 30 minutes or less, but obtained the opposite response in animals breathing $\mathrm{CO}_{2}$ for periods longer than 55 minutes. Observations made on man during

1 This work was supported by a grant from the $\mathrm{Na}$ tional Tuberculosis Association, made possible by a special bequest from the estate of Grace Velie Harris. Preliminary report: Bull. New York Acad. Med., 1952, 28, 543. studies of the acidosis associated with general anesthesia will form the basis of this report. The immediate response of anesthetized man to acute respiratory acidosis is similar to that observed by Shaw and Messer (2).

\section{METHODS}

Arterial blood $\mathrm{pH}$ determinations were obtained at frequent intervals by means of a special glass electrode $\mathrm{pH}$ meter (6) which permits transfer of blood from an indwelling arterial cannula directly into a glass electrode for immediate measurement. Samples of arterial blood were obtained periodically under anaerobic conditions for determination of oxygen $\left(\mathrm{O}_{2_{b}}\right)$ and carbon dioxide content $\left(\mathrm{CO}_{2_{b}}\right)$ of whole blood, and the $\mathrm{CO}_{2}$ content $\left(\mathrm{CO}_{2_{p}}\right)$ of plasma by the manometric method of Goldstein, Gibbon, Allbritten, and Stayman (7). This method has been proven valid for the analysis of blood samples which contain the commonly used volatile anesthetic agents (8). The hematocrit $(\mathrm{Ht})$ was determined by centrifugation in Sanford-Magath tubes or by a calculation based on the difference between the content of carbon dioxide in the whole blood and the plasma, using the nomogram of Van Slyke and Sendroy (9). Oxygen saturation (Sat.) was calculated from the oxygen content of whole blood and an oxygen capacity based on the hematocrit according to the relationship given by the nomogram of Van Slyke and Sendroy. $\mathrm{CO}_{2}$ tension $\left(\mathrm{PoO}_{2}\right)$ was calculated from arterial plasma $\mathrm{pH}$ and $\mathrm{CO}_{2}$ content using the Henderson-Hasselbach equation and the constants: $\mathrm{pK}^{\prime}=6.10, \alpha_{\mathrm{CO}_{2}}=0.0301$. The amount of cation in excess of the non-buffer anion of whole blood, the buffer base (BB), was read from the nomogram of Singer and Hastings (10).

In most instances, the analytical procedures were completed within two hours of the drawing of the blood samples. All analyses were performed in duplicate. The reproducibility (one standard deviation) of the analytical methods as determined in collateral studies $(6,8)$ were as follows: $\mathrm{pH} \pm 0.01 ; \mathrm{CO}_{2_{\mathrm{b}}} \pm 0.12 \mathrm{mM}$ per L.; $\mathrm{CO}_{2 \mathrm{p}}$ $\pm 0.09 \mathrm{mM}$ per $\mathrm{L}$.; $\mathrm{O}_{2 \mathrm{~b}} \pm 0.18$ vol. per cent $\mathrm{Ht} \pm 4$ per cent.

A test of the reliability of the methods was conducted on arterial blood of five healthy, unanesthetized, adult volunteers (Table I). For comparison, $\mathbf{P C O}_{2}$ was determined directly by a semi-micro method (11). The mean $\mathrm{P}_{\mathrm{CO}_{2}}$ calculated from $\mathrm{pH}$ and $\mathrm{CO}_{2}$ was $2.2 \mathrm{~mm}$. 
TABLE I

Direct and indirect measurements of $P_{\mathrm{CO}_{2}}$ of arterial blood of healthy, unanesthetized adult subjects *

\begin{tabular}{|c|c|c|c|c|c|c|c|}
\hline Subj. & $\underset{m M / L}{\operatorname{cog}_{2 p}}$ & $\underset{\mathrm{pH}}{2}$ & $\underset{\text { direct }}{\mathrm{P}_{2}} \underset{\mathrm{Bg}}{\mathrm{B}}$ & $\begin{array}{c}\mathbf{4} \\
\text { indirect } \\
\text { mim. } B_{8}\end{array}$ & $\stackrel{5}{\mathbf{5}}$ & $\underset{m E Q . / L}{\stackrel{6}{\mathrm{BB}}}$ & $\underset{m E q . / L .}{\stackrel{7}{\text { BB }}}$ \\
\hline $\begin{array}{l}\text { D. H. } \\
\text { C. W. } \\
\text { F. H. } \\
\text { A. B. } \\
\text { A. B. } \\
\text { M. B. }\end{array}$ & $\begin{array}{l}26.65 \\
26.70 \\
26.94 \\
26.04 \\
26.04 \\
26.58\end{array}$ & $\begin{array}{l}7.39 \\
7.37 \\
7.37 \\
7.36 \\
7.37 \\
7.37\end{array}$ & $\begin{array}{c}41.6 \\
(29.3) \\
42.5 \\
39.8 \\
40.6 \\
39.8\end{array}$ & $\begin{array}{l}41.7 \\
43.1 \\
44.1 \\
43.6 \\
42.7 \\
43.5\end{array}$ & $\begin{array}{l}7.39 \\
7.39 \\
7.40 \\
7.39 \\
7.41\end{array}$ & $\begin{array}{l}48.1 \\
47.8 \\
48.8 \\
47.0 \\
47.7 \\
46.8\end{array}$ & $\begin{array}{l}48.1 \\
49.4 \\
48.2 \\
48.0 \\
48.0\end{array}$ \\
\hline Means & 26.49 & 7.371 & 40.9 & 43.1 & 7.396 & 47.7 & 48.3 \\
\hline
\end{tabular}

* The first three columns present measured values; the last four columns contain derived values. The values in columns 4 and 6 were derived from data in columns 1 and 2 ; the values in columns 5 and 7 were derived from data in columns 1 and 3 . The buffer used as a standard for pH measurements was represented by the manufacturer to have a pH of $6.96 \pm 0.02$ at $37^{\circ} \mathrm{C}$. Two independent studies were performed on subject $\mathrm{A}$. B. at different times. The value for direct $\mathrm{PCO}_{2}$ in the second row was assumed to reflect an error in method and is not included in the average.

$\mathrm{Hg}$ higher than the mean direct $\mathrm{P}_{\mathrm{co}_{2}}$. The mean $\mathrm{BB}$, based on $\mathrm{pH}$ and $\mathrm{CO}_{2 \mathrm{p}}$, was $47.7 \mathrm{mEq}$. per $\mathrm{L}$., as compared with a mean of $48.3 \mathrm{mEq}$. per $\mathrm{L}$. based on direct $\mathrm{PoO}_{2}$ and $\mathrm{CO}_{2 \mathrm{p}}$. All values were within the normal range, although the values based on $\mathrm{pH}$ and $\mathrm{CO}_{2}$ tended to be slightly more acidotic than those based on direct $\mathrm{Pooz}$ and $\mathrm{CO}_{2}$.

The estimations of $\mathrm{PoO}_{2}$ are probably reliable to within 5 per cent of the observed $\mathrm{Pco}_{2}$. The random error in the estimation of buffer base approximates $1.0 \mathrm{mEq}$. per L. Oxygen saturation may have been underestimated during this study by as much as 10 per cent since the hematocrit is an unreliable index of oxygen capacity. Errors of this magnitude in estimation of oxygen saturation have an insignificant effect on the calculation of buffer base (10), and hence satisfied the requirements of this study. No other significance should be ascribed to the values for oxygen saturation reported herein.

In the following discussion the term "respiratory acidosis" will refer to any elevation of $\mathrm{Pco}_{2}$ above $45 \mathrm{~mm}$. $\mathrm{Hg}$; "metabolic acidosis" will denote any measurable reduction of the buffer base.

\section{RESULTS}

Serial estimations of acid-base balance were obtained on 25 patients before and during anesthesia produced by nitrous oxide, cyclopropane, ethylene, thiopental and regional block anesthesia, alone and in various combinations, and for from one to four hours following the termination of anesthesia (Table II). An average of 7 complete manometric analyses was made during each study; the range was 3 to 15 . An average of 4 manometric analyses was obtained during anesthesia; the range was 2 to 8 . An average of 43 measurements of arterial blood $\mathrm{pH}$ was made during each study.
The average duration of anesthesia was 191 minutes. The surgical operations were representative of a variety of major and minor procedures, including 5 intrapleural procedures (Table II). Anesthesia was prolonged because of the current study in a number of minor operations, such as uterine curettage.

Elevations of $\mathrm{CO}_{2}$ tension exceeding $10 \mathrm{~mm}$. $\mathrm{Hg}$ were observed in 18 subjects, of which 15 exhibited reductions of buffer base exceeding 3 millequivalents per liter of blood. Table III summarizes the measurements obtained on a representative subject from this group. R. S. had an essentially normal $\mathrm{CO}_{2}$ tension before induction of anesthesia, but exhibited a mild degree of metabolic acidosis as evidenced by a buffer base of 45 $\mathrm{mEq}$. per L. Following induction of anesthesia the $\mathrm{pH}$ fell and the $\mathrm{P}_{\mathrm{OO}_{2}}$ became elevated to 55 $\mathrm{mm}$. Hg. Although the $\mathrm{P}_{\mathrm{CO}_{2}}$ increased to $75 \mathrm{~mm}$. $\mathrm{Hg}$, the plasma $\mathrm{CO}_{2}$ content remained constant within $1 \mathrm{mM}$ per $\mathrm{L}$. This is expressed as a sharp initial reduction of the buffer base and further progressive reduction totalling $6.6 \mathrm{mEq}$. per L. Within one-half hour following the termination of anesthesia, the $\mathrm{P}_{\mathrm{CO}_{2}}$ had returned to $50 \mathrm{~mm}$. $\mathrm{Hg}$ and the metabolic acidosis had begun to resolve.

The greatest changes of $\mathrm{P}_{\mathrm{CO}_{2}}$ and buffer base encountered in these 25 consecutively-studied procedures, during which anesthesia was produced by agents other than diethyl ether, are presented in Table IV. Data obtained during ether anesthesia are not included since it has been shown $(12,13)$ 
TABLE II

A summary of the number of measurements carried out on anesthetized patients*

\begin{tabular}{|c|c|c|c|c|c|c|c|c|c|}
\hline \multirow[b]{3}{*}{ Subject } & \multirow[b]{3}{*}{ Anestheaia } & \multirow{3}{*}{$\begin{array}{c}\text { Duration } \\
\text { of anes- } \\
\text { thesia }\end{array}$} & \multirow[b]{3}{*}{ Operation } & \multicolumn{2}{|c|}{$\begin{array}{l}\text { Number of manometric } \\
\text { analyses }\end{array}$} & \multirow{3}{*}{$\begin{array}{l}\text { Number } \\
\text { of pH } \\
\text { measure- } \\
\text { ments }\end{array}$} & \multirow{2}{*}{\multicolumn{3}{|c|}{ Oxygen saturation }} \\
\hline & & & & \multirow{2}{*}{$\begin{array}{c}\text { During } \\
\text { anes: } \\
\text { thesia }\end{array}$} & \multirow[b]{2}{*}{ Total } & & & & \\
\hline & & & & & & & Before & During & End \\
\hline $\begin{array}{l}\text { H. W. } \\
\text { J. R. } \\
\text { P. B. } \\
\text { T. F. } \\
\text { O. T. } \\
\text { I. C. }\end{array}$ & $\begin{array}{l}\text { Cyclopropane } \\
\text { Peridural } \\
\text { Thiopental- } \mathrm{N}_{2} \mathrm{O} \\
\text { Thiopental- } \mathrm{N}_{2} \mathrm{O} \\
\text { Cyclopropane } \\
\text { Thiopental- } \mathrm{N}_{2} \mathrm{O}\end{array}$ & $\begin{array}{l}\min . \\
127 \\
140 \\
133 \\
165 \\
120 \\
300\end{array}$ & $\begin{array}{l}\text { D \& C } \\
\text { Prostatectomy } \\
\text { Midthigh amputation } \\
\text { Herniorrhaphy } \\
\text { D \& C } \\
\text { Vaginal plasty and } \\
\text { hysterectomy }\end{array}$ & $\begin{array}{l}8 \\
2 \\
3 \\
2 \\
4 \\
4\end{array}$ & $\begin{array}{r}15 \\
4 \\
3 \\
5 \\
7 \\
7\end{array}$ & $\begin{array}{l}42 \\
21 \\
21 \\
40 \\
53 \\
55\end{array}$ & $\begin{array}{r}\% \\
79 \\
86 \\
78 \\
90 \\
100\end{array}$ & $\begin{array}{r}\% \\
92 \\
79 \\
78 \\
79 \\
100 \\
97\end{array}$ & $\begin{array}{r}78 \\
100 \\
95\end{array}$ \\
\hline $\begin{array}{l}\text { M. L. } \\
\text { C. E. } \\
\text { R. T. } \\
\text { A. S. }\end{array}$ & $\begin{array}{l}\text { Thiopental- } \mathrm{N}_{2} \mathrm{O} \text {-curare } \\
\text { Cyclopropane } \\
\text { Cyclopropane } \\
\text { Epidural-meperidine- } \\
\text { thiopental }\end{array}$ & $\begin{array}{l}225 \\
155 \\
170 \\
270\end{array}$ & $\begin{array}{l}\text { Gastrectomy } \\
\text { D \& C } \\
\text { Ankle fusion } \\
\text { Cholecystectomy }\end{array}$ & $\begin{array}{r}3 \\
4 \\
11 \\
4\end{array}$ & $\begin{array}{r}5 \\
7 \\
15 \\
7\end{array}$ & $\begin{array}{l}18 \\
40 \\
40 \\
39\end{array}$ & $\begin{array}{l}82 \\
93 \\
87\end{array}$ & $\begin{array}{r}84 \\
100 \\
79\end{array}$ & $\begin{array}{l}96 \\
74\end{array}$ \\
\hline $\begin{array}{l}\text { E. T. } \\
\text { M.S. } \\
\text { E. J. } \\
\text { S. E. } \\
\text { J. E. } \\
\text { G. R. } \\
\text { H.C. } \\
\text { J. V. } \\
\text { E. C. } \\
\text { R. S. } \\
\text { J. B. } \\
\text { R. D. } \\
\text { G. H. }\end{array}$ & $\begin{array}{l}\text { Cyclopropane } \\
\text { Cyclopropane } \\
\text { Cyclopropane } \\
\text { Cyclopropane } \\
\text { Cyclopropane } \\
\text { Cyclopropane } \\
\text { Cyclopropane } \\
\text { Cyclopropane } \\
\text { Cyclopropane-curare } \\
\text { Cyclopropane } \\
\text { Cyclopropane } \\
\text { Cyclopropane-thiopental } \\
\text { Cyclopropane }\end{array}$ & $\begin{array}{l}375 \\
140 \\
135 \\
180 \\
130 \\
165 \\
112 \\
155 \\
123 \\
165 \\
160 \\
210 \\
285\end{array}$ & $\begin{array}{l}\text { Gastrectomy } \\
\text { Closure gastrostomy } \\
\text { Herniorrhaphy } \\
\text { Herniorrhaphy } \\
\text { D \& C } \\
\text { D \& C } \\
\text { Herniorrhaphy } \\
\text { Thoracotomy } \\
\text { Exploratory laporotomy } \\
\text { D \& C } \\
\text { Thoracotomy } \\
\text { Segmental resection } \\
\text { Ligation of ductus } \\
\text { arteriosis }\end{array}$ & $\begin{array}{l}4 \\
2 \\
3 \\
5 \\
4 \\
3 \\
3 \\
3 \\
3 \\
5 \\
3 \\
5 \\
4\end{array}$ & $\begin{array}{l}6 \\
6 \\
6 \\
8 \\
8 \\
7 \\
6 \\
6 \\
6 \\
7 \\
8 \\
7 \\
7\end{array}$ & $\begin{array}{l}53 \\
29 \\
28 \\
44 \\
33 \\
41 \\
22 \\
72 \\
55 \\
37 \\
59 \\
43 \\
63\end{array}$ & $\begin{array}{l}72 \\
73 \\
82 \\
90 \\
85 \\
81 \\
84 \\
85 \\
78 \\
86 \\
88 \\
85 \\
77\end{array}$ & $\begin{array}{l}79 \\
79 \\
90 \\
96 \\
96 \\
92 \\
89 \\
96.4 \\
83 \\
84 \\
88 \\
84 \\
89\end{array}$ & $\begin{array}{r}79 \\
79 \\
90 \\
94 \\
85 \\
85 \\
98 \\
100 \\
83 \\
89 \\
90 \\
82 \\
80\end{array}$ \\
\hline B. D. & $\begin{array}{l}\text { Thiopental- } \mathrm{N}_{2} \mathrm{O}- \\
\text { cyclopropane }\end{array}$ & 335 & Pneumonectomy & 5 & 7 & 75 & 82 & 94 & 89 \\
\hline L. W. & Cyclopropane & 290 & Gastrectomy & 4 & 8 & 50 & 72 & 83 & 80 \\
\hline Averag & & 191 & & 4.1 & 7.1 & 42.9 & 83.3 & 87.7 & 86.8 \\
\hline
\end{tabular}

*In the last three columns summarizing oxygen saturation the words "before," "during," and "end" have the same time significance as described in the footnote to Table IV.

that ether induces a metabolic acidosis of variable degree, depending on the subject, which is independent of changes in $\mathrm{P}_{\mathrm{OO}_{2}}$. The cases are arranged in order of ascending magnitude of $\mathrm{P}_{\mathrm{CO}_{2}}$ elevation. The greatest depressions of buffer base coincided with the greatest elevations of $\mathrm{P}_{\mathrm{OO}_{2}}$. This relationship is indicated in Figure 1.

The regression equation describing the best-

TABLE III

Measurements obtained on a representative subject ${ }^{*} \dagger$

\begin{tabular}{|c|c|c|c|c|c|c|c|c|}
\hline Time & pH & $\mathrm{CO}_{z p}$ & $\mathrm{O}_{\mathrm{b}}$ & Ht & Sat. & $\mathrm{PCO}_{2}$ & BB & $\triangle \mathrm{BB}$ \\
\hline \multirow{3}{*}{$\begin{array}{r}10: 53 \\
10: 55 \\
11: 26 \\
12: 04 \\
12: 23 \\
1: 09 \\
1: 42 \\
1: 42 \\
2: 14\end{array}$} & \multirow{3}{*}{$\begin{array}{l}7.35 \\
\text { Induction of a } \\
7.24 \\
7.22 \\
7.18 \\
7.10 \\
7.16 \\
\text { End of operat } \\
7.26\end{array}$} & 25.1 & 14.1 & 35.4 & 86.3 & 43.1 & 45.2 & \\
\hline & & $\begin{array}{l}25.6 \\
24.9 \\
25.1 \\
25.6 \\
25.8 \\
\text { tion and an }\end{array}$ & $\begin{array}{r}15.5 \\
14.6 \\
15.1 \\
14.4 \\
14.5 \\
\text { thesia }\end{array}$ & $\begin{array}{l}36.4 \\
36.0 \\
35.5 \\
36.8 \\
35.2\end{array}$ & $\begin{array}{l}91.3 \\
87.3 \\
92.1 \\
83.8 \\
89.8\end{array}$ & $\begin{array}{l}55.6 \\
56.6 \\
62.1 \\
74.9 \\
66.2\end{array}$ & $\begin{array}{l}42.4 \\
41.0 \\
40.8 \\
38.6 \\
40.2\end{array}$ & $\begin{array}{l}-2.8 \\
-4.2 \\
-4.4 \\
-6.6 \\
-5.0\end{array}$ \\
\hline & & 24.1 & 13.4 & 36.0 & 80.3 & 50.2 & 41.5 & -3.7 \\
\hline
\end{tabular}

* R. S., November 5, 1952, Cyclopropane, Dilatation and Curettage.

t $\mathrm{pH}$ values represent the average of at least two independent measurements made within two minutes. Additional measurements of $\mathrm{pH}$ between the indicated times have been omitted from the table. The changes of buffer base, with respect to the control value obtained before induction of anesthesia, are listed in the last column. 


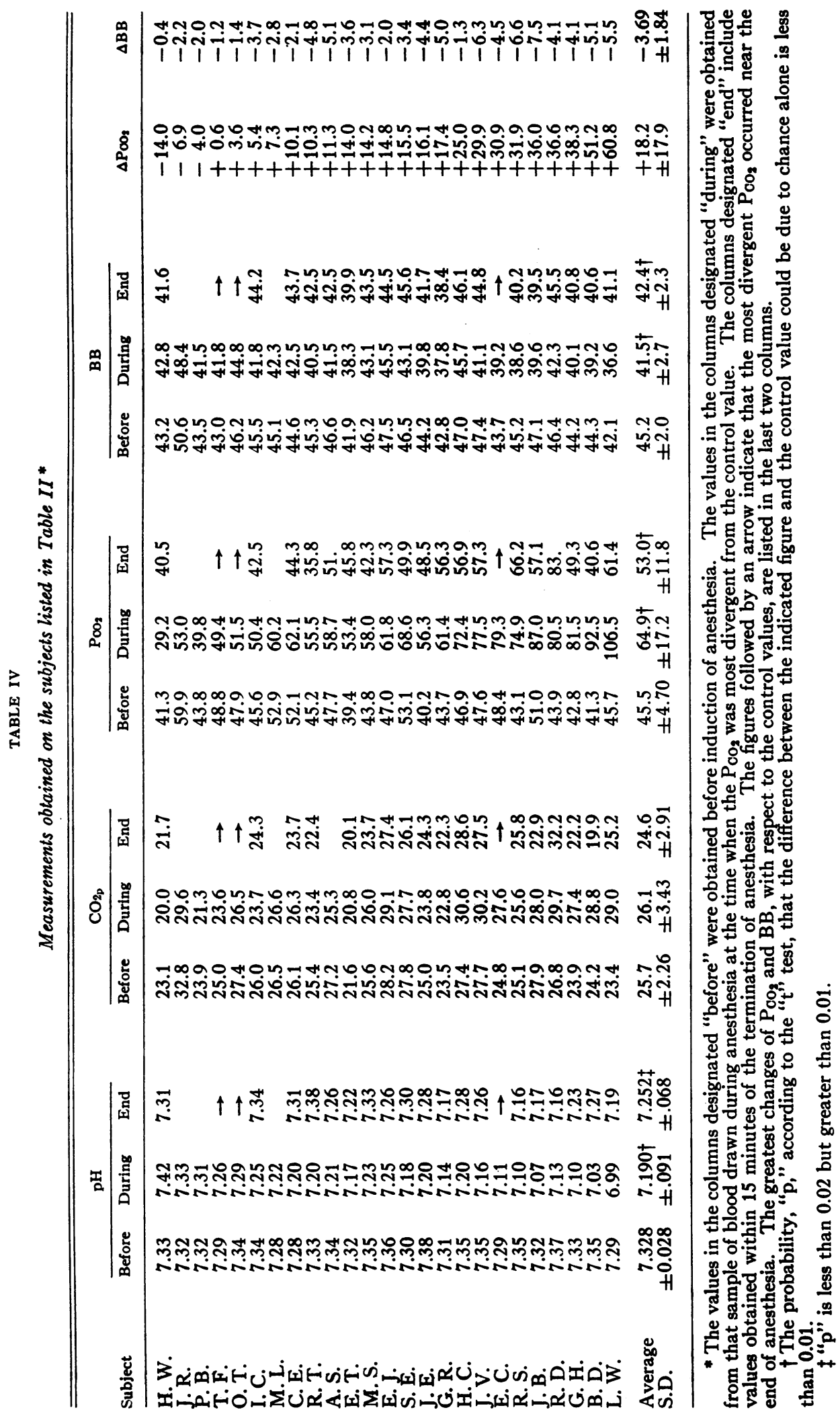


fitting straight line for the points in Figure 1 is: $\mathrm{BB}=2.4 \mathrm{mEq}$. per L. $-0.067\left(\Delta \mathrm{POO}_{2}\right) \pm$ $0.015\left(\Delta \mathrm{P}_{\mathrm{CO}_{2}}\right)$ in which $-2.4 \mathrm{mEq}$. per $\mathrm{L}$. is the change of buffer base expected during an anesthesia conducted without observed deviation of arterial $\mathrm{P}_{\mathrm{CO}_{2}} ;-0.067 \mathrm{mEq}$. per $\mathrm{L}$. is the change of buffer base expected per unit increase of $\mathrm{P}_{\mathrm{OO}_{2}}$; and 0.015 is the standard error of the latter term. The correlation coefficient for these data is -0.65 \pm 0.11 .

The time course of the change of buffer base following a sudden elevation of $\mathrm{P}_{\mathrm{OO}_{2}}$ is illustrated by a representative case summarized in Figure 2. Three features are typical of this response: 1) a decrease in buffer base in the first blood sample drawn after depression of the $\mathrm{pH} ; 2$ ) a tendency for full development of the metabolic acidosis to lag behind the elevation of $\mathrm{P}_{\mathrm{CO}_{2}} ; 3$ ) a slow return of the buffer base toward normal following improvement of the ventilation and reestablishment of a more normal $\mathrm{P}_{\mathrm{CO}_{2}}$. In the instance illustrated, the ventilation was not improved until anesthesia was terminated, and the resolution of the metabolic acidosis occurred in the early post-operative period. However, the disappearance of the metabolic acidosis is not dependent on termination of anesthesia; if a respiratory acidosis occurs during anesthesia and is corrected during anesthesia, the depressed buffer base may be seen to rise during anesthesia.

The data of the case illustrated by Figure 2 are replotted in Figure 3, using plasma bicarbonate content and $\mathrm{pH}$ as coordinates, to emphasize the failure of $\mathrm{HCO}_{3 \mathrm{p}}^{-}$to increase following increase in $\mathrm{P}_{\mathrm{CO}_{2}}$ in accordance with the normal buffer line of blood (refer to "The ABC of Acid-Base Chemistry" by Davenport [14] for a detailed treatment of this graph form). The observed curve follows an almost horizontal course during development of acidosis, indicating the rapidity of development of the metabolic acidosis. On the other hand, as a consequence of the slower restitution of the metabolic acidosis, the curve parallels the expected course when the $\mathrm{P}_{\mathrm{CO}_{2}}$ is returned toward normal rapidly.

Figure 4, which summarizes the averages of the extreme values of $\mathrm{BB}$ and $\mathrm{P}_{\mathrm{CO}_{2}}$ observed in 57 consecutive studies, indicates the magnitude of change to be expected as a function of : the period of anesthesia and operation, the type of anesthetic

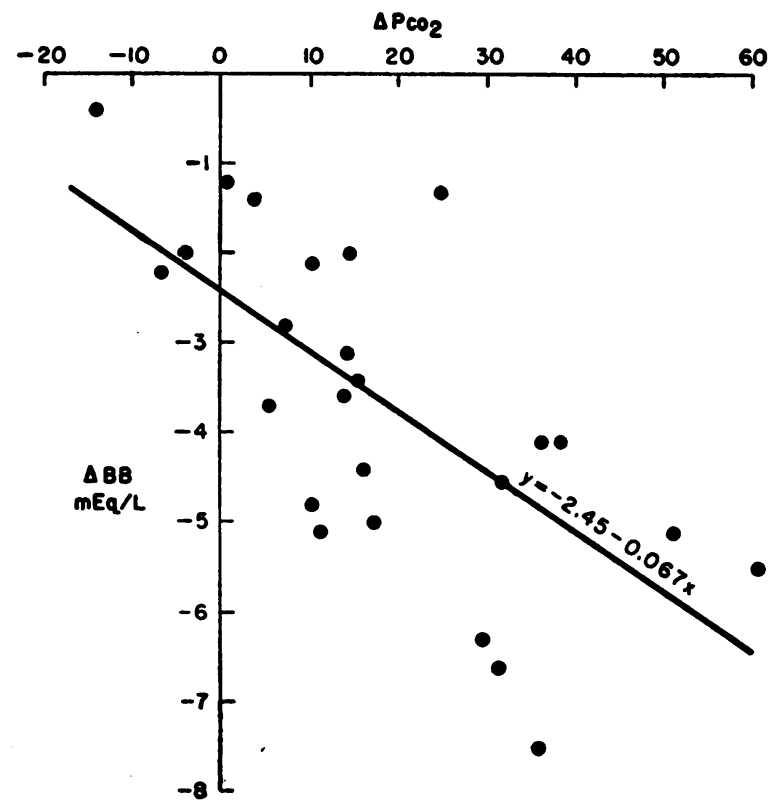

Fig. 1. Correlation of the Changes in Buffer Base ( $\triangle$ BB) With the Changes in Arterial Plasma Carbon Dioxide Tension $\left(\Delta \mathrm{P}_{\mathrm{CO}_{2}}\right)$

See Table IV for details. The solid line represents the best-fitting straight line obtained by the method of least squares. The correlation coefficient for these data is -0.65 .

agent used, and the type of surgical operation performed. These data suggest that surgical patients tend to exhibit a mild metabolic acidosis before anesthesia and operation. The average control buffer base for all groups was $45.5 \mathrm{mEq}$. per $\mathrm{L}$. compared to the mean "normal" value which is reported to be $49 \mathrm{mEq}$. per L. (10) (see also Table I). A respiratory acidosis occurred in all groups during the induction period, and was greatest in those patients subjected to thoracotomy, presumably because the incidence of endotracheal intubation was highest in these groups and the period of hypoventilation was most prolonged. During the induction period a moderate reduction of buffer base occurred which correlated with the elevation of $\mathrm{P}_{\mathrm{OO}_{2}}$, but tended to be greater in the groups receiving ether. Following the production of surgical pneumothorax most patients developed relatively severe respiratory acidosis. Ventilation was maintained at adequate levels most frequently during ether anesthesia for non-thoracic procedures; this is consistent with the known respiratory stimulant action of ether. On the other hand 

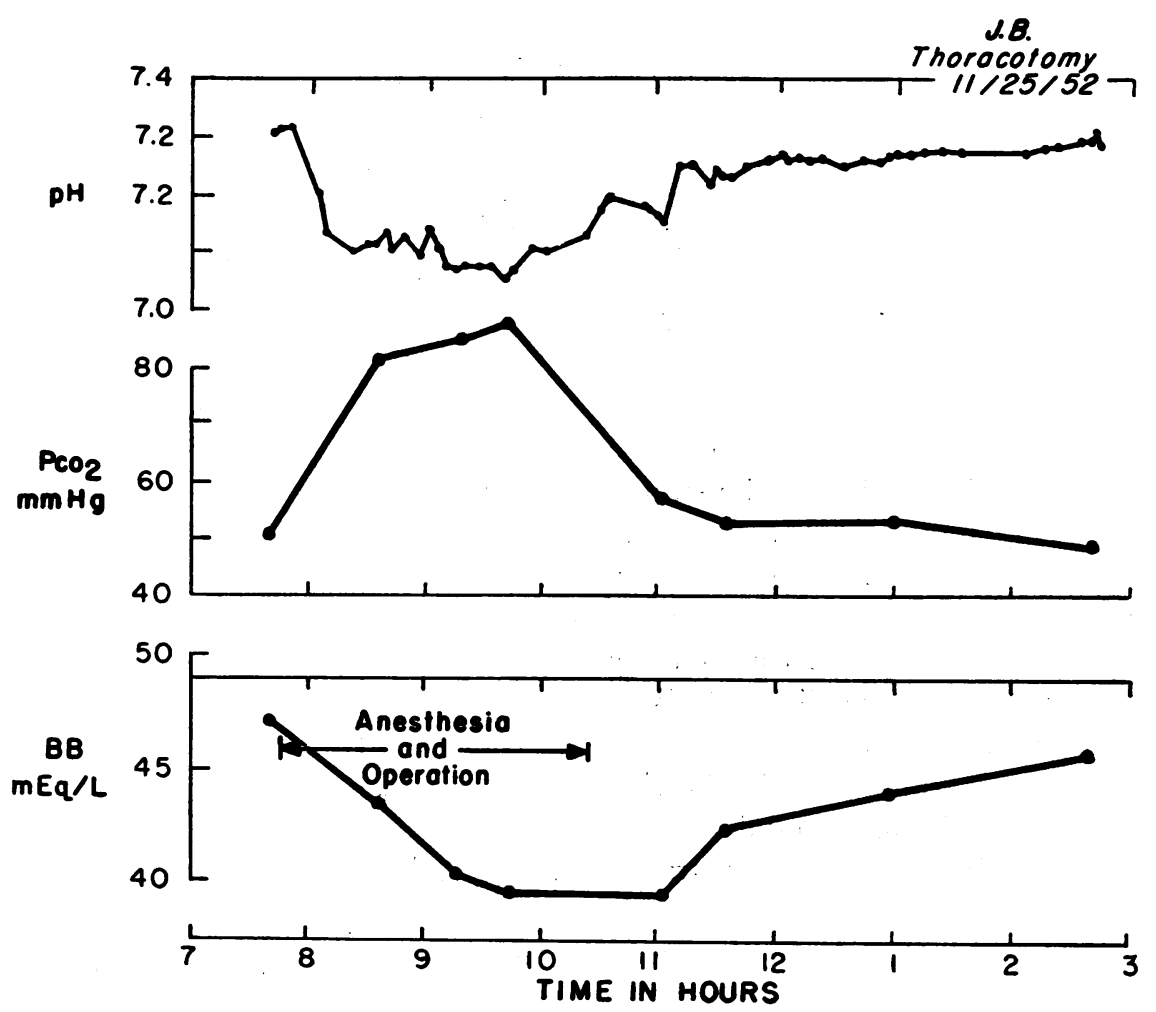

Fig. 2. The Time Course of Changes of pH, Pcon, and Buffer Base During a Representative Case

The arrows indicate the duration of anesthesia and operation. The horizontal coordinates are adjusted to the average "normal" level.

the greatest degrees of metabolic acidosis occurred in this group during the maintenance period. In all groups the reduction of buffer base was maximum during the maintenance period. At the termination of anesthesia and operation ventilation was improved in all groups and resolution of metabolic acidosis had begun. $\mathrm{P}_{\mathrm{CO}_{2}}$ returned to normal levels early in the recovery period. Progressive but incomplete subsidence of the metabolic acidosis was observed during the recovery period.

\section{DISCUSSION}

A metabolic acidosis occurs whenever the normal excess (approximately $49 \mathrm{mEq}$. per L.) of cations over the non-buffer anions of whole blood is reduced. A reduction of this difference can be brought about by a reduction in the total base of blood, or by an increase in the relative concentrations of any of the acids of the blood, including chloride, lactate, ketone bodies, and other highly ionized organic acids. Metabolic acidosis tends to accompany a variety of disturbances of normal physiology and is produced by a diversity of mechanisms, some of which have been extensively defined (as in the accumulation of ketone bodies during uncompensated diabetes, or the loss of sodium during severe diarrhea) and others which remain obscure.

During anesthesia a number of the known causes for production of metabolic acidosis may occur, but are normally not expected to be an obligatory accompaniment of anesthesia and operation. These causes include hemorrhagic shock, anoxemia, hepatic insufficiency, starvation, and diabetes. Ether is the only anesthetic drug among those employed during this investigation which is known to induce a metabolic acidosis directly by the accumulation of lactic acid $(15,16)$.

The reason why certain investigators $(1,3,4)$ have observed consistently an elevation of $\mathrm{CO}_{2}$ combining power during the first hours of respiratory acidosis, while others $(2,5)$ have observed 
a reduction, is not immediately apparent. Anesthesia may be a factor in modifying the cellular response to respiratory acidosis by influencing cell membrane permeability or cellular enzyme reactivity. There is no evidence for the occurrence of such effects during clinical anesthesia, although they have been demonstrated in vitro and in unicellular preparations (17). There is, however, no consistent relationship between the use of anesthesia and the type of response observed. Metabolic alkalosis has occurred during breathing of $\mathrm{CO}_{2}$ mixtures in unanesthetized man (4) and $\operatorname{dog}(1,5)$ and in dogs anesthetized with pentobarbital (3). The same response has been of tained in the dog during respiratory acidosis resulting from morphine-induced respiratory depression (1). On the other hand, a metabolic acidosis has occurred during breathing of $\mathrm{CO}_{2}$ mixtures in unanesthetized man and $\operatorname{dog}(5)$ and in the cat and dog anesthetized with barbital (2). It has also resulted from respiratory depression in anesthetized man, as reported herein, and in anesthetized dogs (Holaday, unpublished data).

Correlations based on degree and duration of respiratory acidosis are similarly unrewarding. Other factors, not yet evaluated, which might determine the type of response include pre-existing differences in hormonal or fluid and electrolyte balances, differences in regional blood flows, and degrees of muscular activity during (or in response to) respiratory acidosis. That activity of skeletal muscle during respiratory acidosis may be a significant factor is indicated by the following two studies in which a reduction of $\mathrm{CO}_{2}$ capacity occurred in paralyzed subjects. Altschule and Sulzbach (18) present values of blood $\mathrm{pH}$ and $\mathrm{CO}_{2}$ content, obtained during $\mathrm{CO}_{2}$ administration to curarized patients, which are consistent with a rapidly developing metabolic acidosis. The descriptions of the changes of blood $\mathrm{pH}$ and alveolar gas $\mathrm{CO}_{2}$ concentration in paralyzed animals during and after diffusion respiration also fit this concept (19). This factor might explain the commonly observed occurrence of severe metabolic acidosis during surgical operations in which interference with normal respiration was encountered (20-23) and the failure to observe it where respiration was known to have been adequate (12).

Failure to obtain a degree of correlation be-

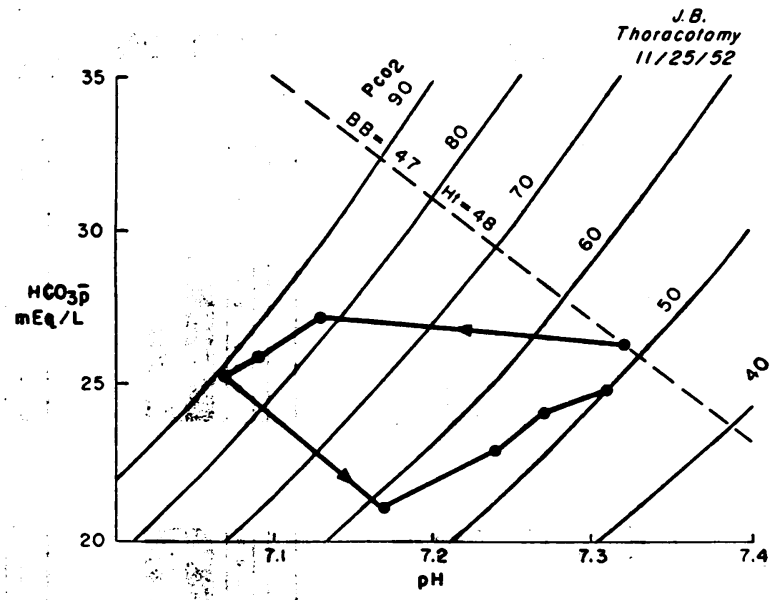

Fig. 3. The Changes of pH and Plasma Bicarbonate Content From the Case Summarized in Figure 2 Plotted as a Function of Changes in $\mathrm{CO}_{2}$. Tension

The arrows indicate the sequence of change. The $\mathrm{P}_{\mathrm{CO}_{2}}$ isobars are established for these coordinates by the Henderson-Hasselbach equation. The dashed line represents the buffer line for saturated blood having a buffer base of $47 \mathrm{mEq}$. per L. and a hematocrit of 48 per cent. Changes of the $\mathrm{P}_{\mathrm{co}}$ of this blood in vitro would be expected to produce changes of $\mathrm{pH}$ and $\mathrm{HCO}_{3 \overline{\mathrm{p}}}$ coinciding with the dashed line. The vertical displacement of a point below the dashed line is an index of the extent of metabolic acidosis incurred.

tween maximum elevation of $\mathrm{P}_{\mathrm{CO}_{2}}$ and depression of buffer base greater than that observed in Figure 4 cannot be construed as evidence against a causal relationship since the degree and duration of the respiratory acidosis were uncontrolled and the periodicity of blood sampling was not correlated with the occurrence of peak $\mathrm{P}_{\mathrm{CO}_{2}}$ changes to establish these quantitatively in every case. Thus the opportunity for obtaining a rigorous "dose-response" relationship was not available during this study. Further studies, including controlled schedules of $\mathrm{P}_{\mathrm{CO}_{2}}$ elevation and measurement of the distribution of the significant contributing electrolytes in the several fluid compartments of the body, will be required to define this response more thoroughly and to obtain information concerning its mechanism of production.

The subjects of this study exhibited mild degrees of respiratory and metabolic acidosis before induction of anesthesia. Although it was not within the scope of the study to determine the causes for this, it is possible that restriction of 


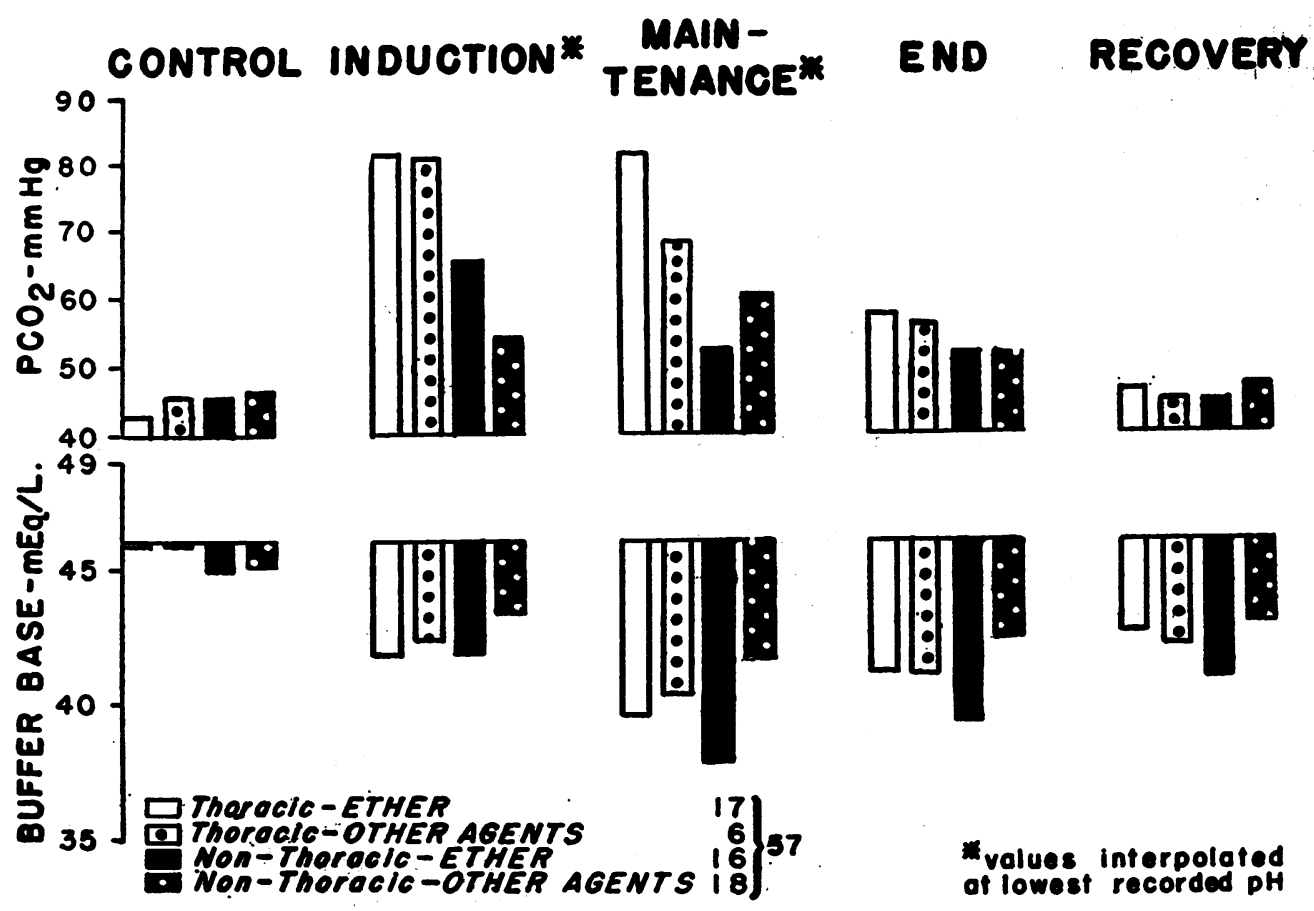

Fig. 4. Summary of Studies, Similar to Those Presented in Table III and Figure 2, Performed Consecutively on 57 Patents

The "control" period is defined as the period immediately preceding induction of anesthesia, but usually following administration of naroctic and belladonna drugs. The "induction" period extended from the initial administration of anesthetic agent until completion of endotracheal intubation and achievement of a relatively stable level of anesthesia; the duration of this period was variable and lasted in some instances for 45 minutes. The "maintenance" period included the remainder of the operative time. The period designated "end" represents a point in time within 15 minutes before or after termination of anesthesia at which a blood sample was obtained. The values given for the "recovery" period represent averages of the last analysis obtained on those subjects who were studied for 30 minutes or more after termination of anesthesia. The average time into the recovery period during which studies were continued was 2 hours; the longest time was 6 hours. The values listed for the "induction" period and "maintenance" period were interpolated, when necessary, to the lowest $\mathrm{pH}$ recorded during the respective periods. The subjects are divided into 4 groups, depending upon whether or not they received ether alone or in combination with other drugs, and whether or not a thoracotomy was performed. The number of subjects included in each group is indicated in the key.

fluids and activity, preanesthetic sedation, consistent errors of determination, and disease were contributory factors.

\section{SUMMARY AND CONCLUSIONS}

The time course of alterations of acid-base balance was obtained on 25 patients before, during and after anesthesia induced with nitrous oxide, cyclopropane, ethylene, thiopental and/or regional block. The $\mathrm{CO}_{2}$ tension of 18 subjects became elevated $10 \mathrm{~mm}$. $\mathrm{Hg}$ or more during anesthesia. Respiratory acidosis was accompanied by a meta- bolic acidosis which tended to be proportional to the extent of $\mathrm{CO}_{2}$ retention. These changes subsided rapidly following termination of anesthesia.

It is concluded that the immediate response to elevation of $\mathrm{CO}_{2}$ tension resulting from depression of respiration in anesthetized man is a metabolic acidosis.

\section{REFERENCES}

1. Henderson, Y., and Haggard, H. W., Respiratory regulation of the $\mathrm{CO}_{2}$ capacity of the blood. High levels of $\mathrm{CO}_{2}$ and alkali. J. Biol. Chem., 1918, 33, 333.

2. Shaw, L. A., and Messer, A. C., The transfer of 
bicarbonate between the blood and tissues caused by alterations of the carbon dioxide concentration in the lungs. Am. J. Physiol., 1932, 100, 122.

3. Giebisch, G., Berger, L., and Pitts, R. F., The extrarenal response to acute acid-base disturbances of respiratory origin. J. Clin. Invest., 1955, 34, 231.

4. Elkinton, J. R., Singer, R. B., Barker, E. S., and Clark, J. K., Effects in man of acute experimental respiratory alkalosis and acidosis on ionic transfers in the total body fluids. J. Clin. Invest., 1955, 34, 1671.

5. Himwich, H. E., Gildea, E. F., Rakieten, N., and DuBois, D., The effects of inhalation of carbon dioxide on the carbon dioxide capacity of arterial blood. J. Biol. Chem., 1936, 113, 383.

6. Holaday, D. A., An improved method for multiple rapid determinations of arterial blood $\mathrm{pH}$. J. Lab. \& Clin. Med., 1954, 44, 149.

7. Goldstein, F., Gibbon, J. H., Jr., Allbritten, F. F., Jr., and Stayman, J. W., Jr., The combined manometric determination of oxygen and carbon dioxide in blood, in the presence of low concentrations of ethyl ether. J. Biol. Chem., 1950, 182, 815.

8. Holaday, D. A., and Verosky, M., The manometric analysis of respiratory gases in blood containing volatile anesthetic agents. I. A comparison of macromethods. J. Lab. \& Clin. Med., 1955, 45, 149.

9. Van Slyke, D.D., and Sendroy, J., Jr., Studies of gas and electrolyte equilibria in blood. XV. Line charts for graphic calculations by the HendersonHasselbalch equation, and for calculating plasma carbon dioxide content from whole blood content. J. Biol. Chem., 1928, 79, 781.

10. Singer, R. B., and Hastings, A. B., An improved clinical method for the estimation of disturbances of the acid-base balance of human blood. Medicine, 1948, 27, 223.

11. Peters, J. P., and Van Slyke, D. D., Quantitative Clinical Chemistry, Volume II. Methods. Baltimore, Williams \& Wilkins Co., 1932, pp. 309-316.

12. Beecher, H. K., Francis, L., and Anfinsen, C. B.,
Metabolic effects of anesthesia in man. I. Acidbase balance during ether anesthesia. J. Pharmacol. \& Exper. Therap., 1950, 98, 38.

13. Bunker, J. P., Brewster, W. R., Smith, R. M., and Beecher, H. K., Metabolic effects of anesthesia in man. III. Acid-base balance in infants and children during anesthesia. J. Applied Physiol., 1952, 5, 233.

14. Davenport, H. W., The ABC of Acid-Base Chemistry, 3rd ed. Chicago, The University of Chicago Press, 1950.

15. Ronzoni, E., Koechig, I., and Eaton, E. P., Ether anesthesia. III. Rôle of lactic acid in the acidosis of ether anesthesia. J. Biol. Chem., 1924, 61, 465.

16. Root, W. S., McAllister, F. F., Oster, R. H., and Solarz, S. D., The effect of ether anesthesia on certain blood electrolytes. Am. J. Physiol., 1940, 131, 449.

17. Danielli, J. F., Cell Physiology and Pharmacology. Amsterdam, N. Y., Elsevier Publishing Co., 1950, Chap. V.

18. Altschule, M. D., and Sulzbach, W. M., Tolerance of the human heart to acidosis: Reversible changes in RS-T interval during severe acidosis caused by administration of carbon dioxide. Am. Heart J., 1947, 33, 458.

19. Draper, W. B., Whitehead, R. W., and Spencer, J. N., Studies of diffusion respiration. III. Alveolar gases and venous blood $\mathrm{pH}$ of dogs during diffusion respiration. Anesthesiology, 1947, 8, 524.

20. Beecher, H. K., and Murphy, A. J., Acidosis during thoracic surgery. J. Thoracic Surg., 1950, 19, 50.

21. Taylor, F. H., and Roos, A., Disturbances in acidbase balance during ether anesthesia. With special reference to the changes occurring during thoracic surgery. J. Thoracic Surg., 1950, 20, 289.

22. Gibbon, J. H., Jr., Allbritten, F. F., Jr., Stayman, J. W., Jr., and Judd, J. M., A clinical study of respiratory exchange during prolonged operations with an open thorax. Ann. Surg., 1950, 132, 611.

23. Etsten, B. J., Respiratory acidosis during intrathoracic surgery: The (Overholt) prone position. J. Thoracic Surg., 1953, 25, 286. 